\title{
POSITIVE EXPRESSION OF NEDD9 IN HEAD AND NECK CANCER IS RELATED TO BETTER SURVIVAL PERIOD
}

\author{
Iva Ledinsky Opačić ${ }^{1}$, Krešimir Gršić ${ }^{2}$ Sanda Šitić ${ }^{3}$, Ivan Penavić ${ }^{4}$, \\ Marija Pastorčić Grgić ${ }^{1}$ and Božena Šarčević ${ }^{3}$ \\ ${ }^{1}$ Division of Head and Neck Surgery, Department of Surgical Oncology, \\ University Hospital for Tumors, Sestre milosrdnice University Hospital Centre, Zagreb, Croatia; \\ ${ }^{2}$ Department of Otorhinolaryngology and Head and Neck Surgery, \\ Zagreb University Hospital Centre, Zagreb, Croatia; \\ ${ }^{3}$ Department of Pathology, University Hospital for Tumors, \\ Sestre milosrdnice University Hospital Centre, Zagreb, Croatia; \\ ${ }^{4}$ Department of Surgical Oncology, University Hospital for Tumors, \\ Sestre milosrdnice University Hospital Centre, Zagreb, Croatia
}

\begin{abstract}
SUMMARY - The aim was to determine immunohistochemical expression of NEDD9 protein in head and neck squamous cell carcinoma (HNSCC) and the possible relation of its expression with primary tumor size $(\mathrm{T})$, regional lymph node status $(\mathrm{N})$, stage of disease (TNM) and survival period. A total of 131 patients with primary tumor localization in the area of oropharynx, hypopharynx and larynx, monitored for at least 5 years after initial surgical treatment were analyzed. The study included 128 male and three female patients, median age 62.0 (range 53.0-68.0) years. Of these, 105 (95\%) patients showed positive NEDD9 expressed by dyed cytoplasm. There were no significant differences in NEDD9 expression according to TNM tumor status. Patients with positive NEDD9 expression had a significantly higher median (IQR) survival time 51.0 (15.0-60.0) months as compared to 22.5 (9.0-55.0) months in patients with negative NEDD9 expression ( $\mathrm{p}=0.048$ ). NEDD9 negative expression, controlled for the influence of other variables included in the Cox's proportional hazards model, had a significant hazard ratio (HR) of 2.10 (95\% CI: 1.23-3.58; $\mathrm{p}=0.006)$. The results of our study showed that NEDD9 expression might be an independent prognostic marker in patients with HNSCC regarding data on overall survival and mortality.
\end{abstract}

Key words: Head and neck neoplasms; Squamous cell carcinoma of head and neck; Immunohistochemistry; Neoplasm staging; Disease-free survival; Mortality

\section{Introduction}

Head and neck squamous cell carcinoma (HN$\mathrm{SCC})$ is the fifth most common cancer in humans in the world and the most common type of tumor of the

Correspondence to: Iva Ledinsky Opačic, $M D$, Division of Head and Neck Surgery, Department of Surgical Oncology, University Hospital for Tumors, Sestre milosrdnice University Hospital Centre, Ilica 197, HR-10000 Zagreb, Croatia

E-mail: iva.ledinsky@gmail.com

Received October 25, 2018, accepted December 12, 2018 upper respiratory and digestive mucosa ${ }^{1}$. This type of cancer is developing due to cumulative genetic changes caused by tobacco and alcoholic carcinogenic agents ${ }^{2,3}$, and viruses (e.g., human papillomavirus) ${ }^{3-5}$, together with genetic predisposition ${ }^{6,7}$. Improved surgical and new radiotherapy techniques, and the introduction of new chemotherapy drugs into multimodal treatment protocols failed to bring satisfactory increase in survival rates over the last few decades ${ }^{8}$. Unsatisfactory progress in the survival of patients with head and neck cancer increases the need for further genetic and 
molecular investigations to explain the onset and biological behavior of this type of cancer. Researchers have recently been focused on the new therapeutic modalities, but new biological prognostic tumor markers in patients with HNSCC were also extensively investigated $^{9-12}$.

Neural precursor cell expressed, developmentally downregulated 9 protein (NEDD9) is included in the CAS protein group that is a component of normal and pathologically changed cells, and is associated with poor prognosis and more frequent metastases, as well as resistance to chemotherapy in various types of can$\operatorname{cer}^{13}$.

In recently published studies, NEDD9 showed altered, typically elevated expression in different malignant diseases such as breast cancer, renal cell carcinoma, hepatocellular carcinoma, lung cancer, gastric cancer, colorectal carcinoma, melanoma and glioblastoma.

Overexpression of NEED9 has been so far associated with a more invasive behavior, metastases, poorer disease-free and overall survival of patients, more advanced TNM staging, advanced differentiation grade and tumor size, with deep invasion and presence of vessel invasion ${ }^{14-25}$.

The goal of this investigation was to determine immunohistochemical expression of NEDD9 protein in HNSCC and find the possible correlation of its expression with the size of primary tumor $(\mathrm{T})$, regional lymph node status $(\mathrm{N})$, disease stage (TNM), survival period and mortality.

\section{Patients and Methods}

In this retrospective study, immunohistochemical expression of NEDD9 protein in HNSCC patients treated at the Division of Head and Neck Surgery, Department of Surgical Oncology, University Hospital for Tumors, Sestre milosrdnice University Hospital Centre, Zagreb, Croatia, was evaluated in the 20002006 period. The archived histopathologic material was used upon approval by the Ethics Committee of the Sestre milosrdnice University Hospital Centre. A total of 131 patients with primary tumor localization in the area of oropharynx, hypopharynx and larynx, monitored for at least 5 years after initial surgical treatment were analyzed (Table 1).

The following criteria were set for inclusion in the study: histopathologic diagnosis of HNSCC, radical
Table 1. Clinical and demographic data on study patients $(N=131)$

\begin{tabular}{|c|c|c|}
\hline $\begin{array}{l}\text { NEDD } 9 \\
\text { expression }\end{array}$ & $\begin{array}{l}\text { Negative expression: } \\
\mathrm{n}(\%) \\
\text { Positive expression: } \\
\mathrm{n}(\%)\end{array}$ & $\begin{array}{l}26(19.8) \\
105(80.2)\end{array}$ \\
\hline Tumor site & $\begin{array}{l}\text { Larynx: } \mathrm{n}(\%) \\
\text { Hypopharynx or } \\
\text { oropharynx: } \mathrm{n}(\%)\end{array}$ & $\begin{array}{l}62(47.3) \\
69(52.7)\end{array}$ \\
\hline$T$ grade & $\begin{array}{l}1: \mathrm{n}(\%) \\
2: \mathrm{n}(\%) \\
3: \mathrm{n}(\%) \\
4: \mathrm{n}(\%)\end{array}$ & $\begin{array}{l}24(18.3) \\
57(43.5) \\
36(27.5) \\
14(10.7)\end{array}$ \\
\hline $\begin{array}{l}\text { T grade } \\
\text { (groups) }\end{array}$ & $\begin{array}{l}\text { Initial (T1-T2): n (\%) } \\
\text { Advanced (T3-T4): } \\
\text { n (\%) }\end{array}$ & $\begin{array}{l}81(61.8) \\
50(38.2)\end{array}$ \\
\hline $\mathrm{N}$ grade & $\begin{array}{l}0: \mathrm{n}(\%) \\
1: \mathrm{n}(\%) \\
2: \mathrm{n}(\%) \\
3: \mathrm{n}(\%)\end{array}$ & $\begin{array}{l}61(46.6) \\
13(9.9) \\
49(37.4) \\
8(6.1)\end{array}$ \\
\hline $\begin{array}{l}\text { N grade } \\
\text { (groups) }\end{array}$ & $\begin{array}{l}\text { N0: } n(\%) \\
\text { N1, } 2 \text { or } 3: n(\%)\end{array}$ & $\begin{array}{l}61(46.6) \\
70(53.4)\end{array}$ \\
\hline $\begin{array}{l}\text { M grade } \\
\text { (groups) }\end{array}$ & $\begin{array}{l}\text { M0: n (\%) } \\
\text { M1: n (\%) }\end{array}$ & $\begin{array}{l}131(100.0) \\
0(0.0)\end{array}$ \\
\hline $\begin{array}{l}\text { Stage of disease } \\
\text { (TNM) }\end{array}$ & $\begin{array}{l}1: \mathrm{n}(\%) \\
2: \mathrm{n}(\%) \\
3: \mathrm{n}(\%) \\
4: \mathrm{n}(\%) \\
\end{array}$ & $\begin{array}{l}20(15.3) \\
20(15.3) \\
25(19.1) \\
66(50.4)\end{array}$ \\
\hline $\begin{array}{l}\text { Stage of disease } \\
\text { (TNM) } \\
\text { (groups) }\end{array}$ & $\begin{array}{l}\text { Initial (1-2): n (\%) } \\
\text { Advanced (3-4): n (\%) }\end{array}$ & $\begin{array}{l}40(30.5) \\
91(69.5)\end{array}$ \\
\hline Radiotherapy & $\begin{array}{l}\text { Without: } \mathrm{n}(\%) \\
\text { Postop: n (\%) }\end{array}$ & \begin{tabular}{|l|}
$32(24.4)$ \\
$99(75.6)$ \\
\end{tabular} \\
\hline Chemotherapy & $\begin{array}{l}\text { No: n (\%) } \\
\text { Yes: n (\%) }\end{array}$ & $\begin{array}{l}119(90.8) \\
12(9.2) \\
\end{array}$ \\
\hline Death outcome & $\begin{array}{l}\text { No: } \mathrm{n}(\%) \\
\text { Yes: } \mathrm{n}(\%)\end{array}$ & $\begin{array}{l}57(43.5) \\
74(56.5)\end{array}$ \\
\hline Death causes & $\begin{array}{l}\text { Local relapse: } \mathrm{n}(\%) \\
\text { Dissemination: } \\
\mathrm{n}(\%) \\
\text { Other causes } \\
\text { indirectly related to } \\
\text { primary disease: } \mathrm{n}(\%)\end{array}$ & $\begin{array}{l}21 / 74(28.4) \\
13 / 74(17.6)\end{array}$ \\
\hline \multicolumn{2}{|c|}{ Age (years): median (IQR) } & $62.0(53.0-68.0)$ \\
\hline \multicolumn{2}{|c|}{$\mathrm{BMI}\left(\mathrm{kg} / \mathrm{m}^{2}\right):$ median $(\mathrm{IQR})$} & $23.9(20.9-27.7)$ \\
\hline \multicolumn{2}{|c|}{ Survival time (months): median (IQR) } & $44.0(12.0-60.0)$ \\
\hline
\end{tabular}

$\mathrm{BMI}=$ body mass index; $\mathrm{IQR}$ = interquartile range 
surgery as the first modality of treatment without intraoperative data on macroscopic presence of residual tumor, available TNM classification at the time of diagnosis, data on the treatment and course of the disease, information on patient survival and death from the disease history, and data from the Cancer Registry of the Croatian Public Health Institute. The study was performed on HNSCC tissue samples embedded in paraffin blocks at the Clinical Unit for Oncologic $\mathrm{Pa}-$ thology, University Hospital for Tumors. Tissue samples were processed by the standard histologic procedure that included 24-48 hour tissue fixation in 10\% buffered formalin. After fixing in formalin, the process of tissue preparation through the upward series of alcohol and xylene, tissue was paraffin embedded. After the diagnosis was verified, the degree of tumor differentiation was established and the histopathologic samples and paraffin blocks were archived. One additional cut of each primary tumor, 2-3 microns thick, was mounted on silanized glass, immunohistochemically dyed with primary mouse anti-human antibody to NEDD9 (clone 2G9, AbCam, USA), and diluted at 1:50 ratio with the dilution buffer (Antibody Diluent, S2023, Dako, Denmark). Before starting the procedure, the samples were dried in a thermostat at $60{ }^{\circ} \mathrm{C}$ for approximately 40 minutes, deparaffinized and rehydrated for antigen detection. All procedures were carried out simultaneously by cooking the Tris/EDTA buffer $\mathrm{pH} 9$ at $97^{\circ} \mathrm{C}$ for 20 minutes in a PT link device (Dako, Denmark). Immunohistochemical staining was performed by automatic processing in a Dako Autostainer Universal Staining System by the streptavidin immunoperoxidase method.

All immunohistochemical staining reagents were included in the visualization kit EnVision Flex High $\mathrm{pH}$ (K8010, Dako, Denmark). Visualization of the specific reaction was made with DAB (diaminobenzidine) chromogenic and contrasting coloration with hematoxylin-eosin.

According to the manufacturer's instructions, a positive immunohistochemical reaction is considered if the cytoplasm is dyed. The percentage of cancer cells stained in high-power fields was estimated by semiquantitative method.

The percentage of positive tumor cells was graded as 0 (negative reaction); + (weak reaction; 1 ): more than $10 \%$ of positive tumor cells; ++ (moderate reaction; 2 ): $11 \%-50 \%$ of positive tumor cells; and +++ (strong reaction; 3 ): more than $51 \%$ of positive tumor cells.

The intensity of staining was recorded as weak (1), moderate (2) and strong (3).

As a result, these two scores (percentage of positive tumor cells and intensity of staining) were multiplied and the immunoreactive score (IRS) was determined as negative $(0 ; 1 ; 2 ; 3)$ and positive $(4 ; 6 ; 9)$.

\section{Statistical methods}

Data are presented in tables and figures. After testing for normality by Kolmogorov-Smirnov test, it was decided to use non-parametric tests in the analyses. Categorical variables were presented as frequency and corresponding percentage, and quantitative variables as median and interquartile range $\left(25^{\text {th }}\right.$ to $75^{\text {th }}$ percentile). Fisher-Freeman-Halton exact test of independence when the contingency table is larger than $2 \times 2$ was used to analyze differences in categorical clinical parameters between NEDD9 expression grades. Mann-Whitney U test was used to analyze differences in survival time between the same groups. KaplanMeier survival analysis with Log-Rank (Mantel-Cox) test was used to analyze survival according to NEDD9 expression for 60-month follow-up. In addition, Cox's proportional hazards model for survival-time model was made to assess multivariate predictive model for time-to-death event data. All p values below 0.05 were considered significant. The IBM SPSS Statistics, version 25.0 data analysis software (https://www.ibm. com/analytics/spss-statistics-software) was used on statistical analyses and graphic images.

\section{Results}

The study included 128 male and three female patients, median age 62.0 (range 53.0-68.0) years. Of these, 105 (95\%) patients showed positive NEDD9 expressed by dyed cytoplasm. Differences in NEDD9 expression according to the size of primary tumor (T), regional lymph node status ( $\mathrm{N}$ status), stage of the disease (TNM) and survival period in months are presented in Table 2. There were significant differences in survival outcome according to NEDD9 expression, i.e. patients with positive NEDD9 expression had a significantly lower mortality rate compared to patients with negative NEDD9 expression: 54 (54.4\%) vs. 20 (76.9\%) $(\mathrm{p}=0.026)$. Also, patients with positive NEDD9 expres- 
Table 2. Differences in NEDD9 expression in relation to the size of primary tumor $(T)$, regional lymph node status (N status), stage of the disease (TNM) and survival period in months (Fisher-Freeman-Halton exact test)

\begin{tabular}{|c|c|c|c|c|}
\hline & \multicolumn{2}{|c|}{ NEDD expression grade } & \multirow{4}{*}{$\mathrm{p}$} \\
\hline & & \multirow{2}{*}{$\begin{array}{l}\text { Negative expression } \\
n=26\end{array}$} & \multirow{3}{*}{$\begin{array}{l}\text { Positive expression } \\
\mathrm{n}=105 \\
\mathrm{n}(\%)\end{array}$} & \\
\hline & & & & \\
\hline & & $\mathrm{n}(\%)$ & & \\
\hline T grade & $\begin{array}{l}1 \\
2 \\
3 \\
4\end{array}$ & $\begin{array}{l}7(26.9) \\
9(34.6) \\
7(26.9) \\
3(11.5)\end{array}$ & $\begin{array}{l}17(16.2) \\
48(45.7) \\
29(27.6) \\
11(10.5)\end{array}$ & 0.554 \\
\hline T grade (groups) & $\begin{array}{l}\text { Initial (T1-T2) } \\
\text { Advanced (T3-T4) }\end{array}$ & $\begin{array}{l}16(61.5) \\
10(38.5)\end{array}$ & $\begin{array}{l}65(61.9) \\
40(38.1)\end{array}$ & 1.000 \\
\hline Stage of disease (TNM) & $\begin{array}{l}1 \\
2 \\
3 \\
4\end{array}$ & $\begin{array}{l}6(23.1) \\
4(15.4) \\
5(19.2) \\
11(42.3)\end{array}$ & $\begin{array}{l}14(13.3) \\
16(15.2) \\
20(19.0) \\
55(52.4)\end{array}$ & 0.602 \\
\hline $\begin{array}{l}\text { Stage of disease (TNM); } \\
\text { (groups) }\end{array}$ & $\begin{array}{l}\text { Initial (1-2) } \\
\text { Advanced (3-4) }\end{array}$ & $\begin{array}{l}10(38.5) \\
16(61.5)\end{array}$ & $\begin{array}{l}30(28.6) \\
75(71.4)\end{array}$ & 0.348 \\
\hline $\mathrm{N}$ grade & $\begin{array}{l}0 \\
1 \\
2 \\
3\end{array}$ & $\begin{array}{l}13(50.0) \\
3(11.5) \\
8(30.8) \\
2(7.7)\end{array}$ & $\begin{array}{l}48(45.7) \\
10(9.5) \\
41(39.0) \\
6(5.7)\end{array}$ & 0.818 \\
\hline $\mathrm{N}$ grade (groups) & $\begin{array}{l}\text { Negative (N0) } \\
\text { Positive (N 1, } 2 \text { or } 3)\end{array}$ & $\begin{array}{l}13(50.0) \\
13(50.0)\end{array}$ & $\begin{array}{l}48(45.7) \\
57(54.3)\end{array}$ & 0.827 \\
\hline Tumor site & $\begin{array}{l}\text { Larynx } \\
\text { Hypopharynx or oropharynx }\end{array}$ & $\begin{array}{l}12(46.2) \\
14(53.8)\end{array}$ & $\begin{array}{l}50(47.6) \\
55(52.4)\end{array}$ & 1.000 \\
\hline Death outcome & $\begin{array}{l}\text { No } \\
\text { Yes }\end{array}$ & $\begin{array}{l}6(23.1) \\
20(76.9)\end{array}$ & $\begin{array}{l}51(48.6) \\
54(54.4)\end{array}$ & 0.026 \\
\hline Cumulative survival time & onths): median (IQR) & $22.5(9.0-55.0)$ & $51.0(15.0-60.0)$ & 0.048 \\
\hline
\end{tabular}

$\mathrm{IQR}=$ interquartile range analyzed with Mann-Whitney $\mathrm{U}$ test

sion had a significantly higher median (interquartile range, IQR) survival time: 51.0 (15.0-60.0) months compared to 22.5 (9.0-55.0) months in patients with negative NEDD9 expression ( $\mathrm{p}=0.048$ ).

Kaplan-Meier survival analysis and Log-Rank (Mantel-Cox) test also yielded significant difference in survival rate, indicating that patients with positive NEDD9 expression had better survival $(\mathrm{p}=0.020)$ (Fig. 1).

The Cox's proportional hazards model produced a survival function that predicted the probability that the death event had occurred within 60 -month follow-up for the given values of predictor variables. Regression model was statistically significant $\left(\chi^{2}=38.04\right.$, $\mathrm{df}=8 ; \mathrm{p}<0.001)$. NEDD9 negative expression, con- trolled for the influence of other variables included in the model, had a significant hazard ratio (HR) of 2.10 (95\% confidence interval (CI): 1.23-3.58; $\mathrm{p}=0.006$ ). This result indicated the significance of NEDD9 expression in survival rate in the multivariate survival model and negative NEDD9 expression should be considered as important survival predictor.

\section{Discussion}

The NEDD9 is labeled as a protein that increases the metastatic potential of melanoma ${ }^{14}$. Natarajan et al. found NEDD9 to have an important role in the invasive behavior of glioblastoma cells ${ }^{15}$. Expression of the growth hormone receptor (GHR) and NEDD9 was 


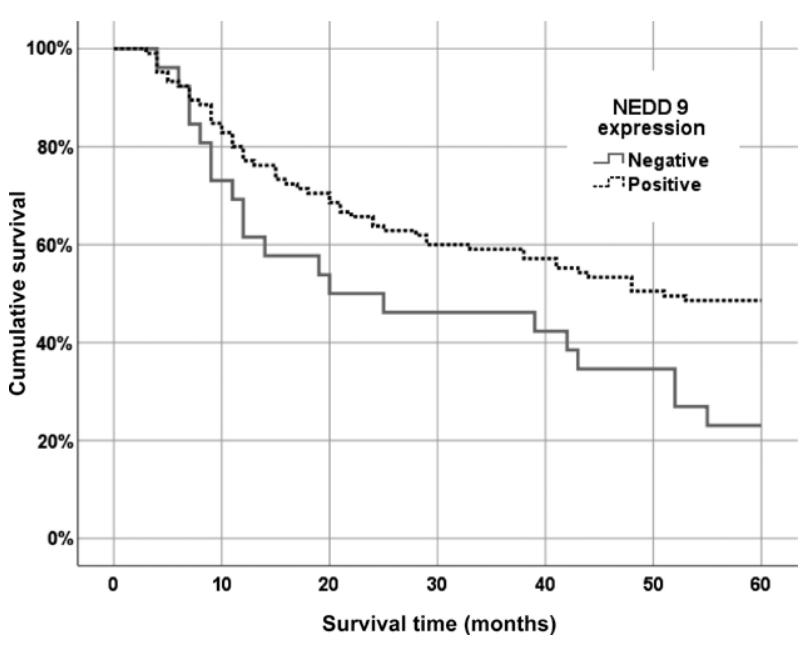

Fig. 1. Cumulative survival regarding NEDD9 expression for 60-month follow-up: Kaplan-Meier survival analysis; Log-Rank (Mantel-Cox) test $(p=0.020)$.

analyzed in breast cancer and association with tumor aggressiveness was found ${ }^{16,17}$. Furthermore, both proteins showed increased expression in epithelial and stromal compartments of primary ductal invasive breast carcinomas and their axillary lymph node metastases in comparison to non-metastatic tumors ${ }^{16}$. An important role in the carcinogenesis of renal cell carcinoma (RCC) was demonstrated by low expression of NEDD9 in normal renal tissues and high expression in RCC tissues ${ }^{18}$. Patients with verified hepatocellular carcinoma (HCC) and high expression of NEDD9 showed poorer recurrence-free interval and overall survival versus those with low expression of NEDD9. These results suggest that NEDD9 may be a prognostic biomarker for HCC, including early-stage tumor and alfa-fetoprotein normal patients ${ }^{19}$. NEDD9 pro- $^{-}$ motes lung cancer metastasis ${ }^{20}$. Overexpression of NEDD9 in patients with lung adenocarcinoma has been strongly correlated with staging, grade and tumor size, demonstrating poor prognosis ${ }^{21}$. Patients with gastric carcinoma showed higher NEDD9 expression in advanced tumors (TNM stages III and IV), deep invasion (T3, T4), presence of vessel invasion, lymph node and distant metastases, indicating that NEDD9 overexpression was involved in the progression of gastric cancer ${ }^{22}$. Additionally, high expression of NEDD9 was significantly associated with poor prognosis and the expression of NEDD9 was an independent prognostic factor ${ }^{22}$. A study conducted by another group of
Chinese investigators revealed that the more advanced clinical TNM stage of gastric carcinoma corresponded to higher expression level of NEDD923. According to their results, NEDD9 is a tumor-promoting factor and thus could be used as an independent biomarker for poor survival ${ }^{23}$. In colorectal cancer, NEDD9 plays an important role in tumor genesis and cancer progression. Furthermore, increased NEDD9 expression was significantly correlated with advanced TNM stage, $\mathrm{pT}$ grade, $\mathrm{pN}$ and $\mathrm{pM}$ status, and shorter overall survival ${ }^{24}$.

On the contrary, in pancreatic adenocarcinoma, NEDD9 did not show any statistical correlation with tumor stage and grade, gender or patient surviva ${ }^{25}$. Polymerase chain reaction of nasopharyngeal carcinoma biopsy samples confirmed the significant decline in NEDD9 mRNA expression in cancer tissues compared to the adjacent non-tumor tissue ${ }^{26}$.

To the best of our knowledge, this is the first study analyzing the grade of immunohistochemical staining of NEDD9 protein in HNSCC in relation to the size of tumor (T), clinical stage of disease (TNM) and patient survival. Immunohistochemical expression of NEDD9 was over 95\%, showing variability in semiquantitative expression. The group with negative NEDD9 expression had a significantly higher mortality when compared to the group with positive NEDD9 expression. As NEDD9 expression was not significantly correlated with tumor size, $\mathrm{N}$ status and disease stage, these results imply that NEDD9 expression is a significant independent indicator of mortality. The mean survival of NEDD9 negative patients was significantly lower when compared to NEDD9 positive patients. The results of our study support the assumption that NEDD9 expression might be an independent prognostic marker in patients with HNSCC considering data on survival time and mortality.

\section{References}

1. Ferreira MB, De Souza JA, Cohen EE. Role of molecular markers in the management of head and neck cancers. Curr Opin Oncol. 2011 May;23(3):259-64. doi: 10.1097/CCO. 0b013e328344f53a.

2. Jethwa AR, Khariwala SS. Tobacco-related carcinogenesis in head and neck cancer. Cancer Metastasis Rev. 2017 Sep;36 (3):411-23. doi: 10.1007/s10555-017-9689-6.

3. Farsi NJ, Rousseau MC, Schlecht N, Castonguay G, Allison P, Nguyen-Tan PF, et al. Aetiological heterogeneity of head and neck squamous cell carcinomas: the role of human papilloma- 
virus infections, smoking and alcohol. Carcinogenesis. 2017 Dec 7;38(12):1188-95. doi: 10.1093/carcin/bgx106.

4. Sano D, Oridate N. The molecular mechanism of human papillomavirus-induced carcinogenesis in head and neck squamous cell carcinoma. Int J Clin Oncol. 2016 Oct;21(5):819-26. doi: 10.1007/s10147-016-1005-x.

5. Sturgis EM,Wei Q. Genetic susceptibility-molecular epidemiology of head and neck cancer. Curr Opin Oncol. 2002 May;14(3):310-7. PMID: 11981277

6. Michmerhuizen NL, Birkeland AC, Bradford CR, Brenner JC. Genetic determinants in head and neck squamous cell carcinoma and their influence on global personalized medicine. Genes Cancer. 2016 May;7(5-6):182-200. doi: 10.18632/genesandcancer.110.

7. Gingerich MA, Smith JD, Michmerhuizen NL, Ludwig M, Devenport S, Matovina C, et al. Comprehensive review of genetic factors contributing to head and neck squamous cell carcinoma development in low-risk, nontraditional patients. Head Neck. 2018 May;40(5):943-54. doi: 10.1002/hed.25057.

8. Kiong KL, de Souza NN, Sultana R, Iyer NG. Meta-analysis of induction chemotherapy as selection marker for chemoradiation in the head and neck. Laryngoscope. 2018 Jul;128(7):1594601. doi: 10.1002/lary.27011.

9. Ren ZH, Lin CZ, Cao W, Yang R, Lu W, Liu ZQ, et al. CD73 is associated with poor prognosis in HNSCC. Oncotarget. 2016 Sep 20;7(38):61690-702. doi: 10.18632/oncotarget. 11435.

10. Lu L, Zhu G, Zeng H, Xu Q, Holzmann K. High tRNA transferase NSUN2 gene expression is associated with poor prognosis in head and neck squamous carcinoma. Cancer Invest. 2018 Apr 21;36(4):246-53. doi: 10.1080/07357907.2018.1466896.

11. Wang Y, Chen C, Wang X, Jin F, Liu Y, Liu H, et al. Lower DSC1 expression is related to the poor differentiation and prognosis of head and neck squamous cell carcinoma (HNSCC). J Cancer Res Clin Oncol. 2016 Dec;142(12):2461-8. doi: 10.1007/s00432-016-2233-1.

12. Münscher A, Prochnow S, Gulati A, Sauter G, Lörincz B, Blessmann $\mathrm{M}$, et al. Surviving expression in head and neck squamous cell carcinomas is frequent and correlates with clinical parameters and treatment outcomes. Clin Oral Investig. (Internet) 2018 Apr 18. doi: 10.1007/s00784-018-2444-8. Available from: https://link.springer.com/article/10.1007\%2 Fs00784-018-2444-8. Subscription required.

13. Tikhmyanova N, Little JL, Golemis EA. Cas proteins in normal and pathological cell growth control. Cell Mol Life Sci. 2010 Apr;67(7):1025-48. doi: 10.1007/s00018-009-0213-1.

14. Natarajan M, Stewart JE, Golemis EA, et al. HEF1 is a necessary and specific downstream effector of FAK that promotes the migration of glioblastoma cells. Oncogene. $2006 \mathrm{Mar}$ 16;25(12):1721-32. doi: 10.1038/sj.onc. 1209199.
15. Kim M, Gans JD, Nogueira C, et al. Comparative oncogenomics identifies NEDD9 as a melanoma metastasis gene. Cell. 2006 Jun 30;125(7):1269-81. doi: 10.1016/j.cell.2006.06.008.

16. Štajduhar E, Sedić M, Leniček T, Radulović P, Kerenji A, Krušlin B, et al. Expression of growth hormone receptor, plakoglobin and NEDD9 protein in association with tumour progression and metastasis in human breast cancer. Tumour Biol. 2014 Jul;35(7):6425-34. doi: 10.1007/s13277-014-1827-y.

17. Kong C,Wang C,Wang L,Ma M, Niu C, Sun X, et al. NEDD9 is a positive regulator of epithelial-mesenchymal transition and promotes invasion in aggressive breast cancer. PLoS One. 2011;6(7):e22666. doi: 10.1371/journal.pone.0022666.

18. Wang J, Yang WJ, Sun C, Luan Y, Cheng GH, Li KL, et al. siRNA suppression of NEDD9 inhibits proliferation and enhances apoptosis in renal cell carcinoma. Oncol Res. 2014; 22(4):219-24. doi: 10.3727/096504015X14386062091442.

19. Lu P, Wang ZP, Dang Z, Zheng ZG, Li X, Zhou L, et al. Expression of NEDD9 in hepatocellular carcinoma and its clinical significance. Oncol Rep. 2015 May;33(5):2375-83. doi: 10.3892/or.2015.3863.

20. Jin Y, Li F, Zheng C, Wang Y, Fang Z, Guo C, et al. NEDD9 promotes lung cancer metastasis through epithelial-mesenchymal transition. Int J Cancer. 2014 May 15;134(10):2294-304. doi: $10.1002 / \mathrm{ijc} .28568$.

21. Chang JX, Gao F, Zhao GQ, Zhang GJ. Expression and clinical significance of NEDD9 in lung tissues. Med Oncol. 2012 Dec;29(4):2654-60. doi: 10.1007/s12032-012-0213-0.

22. Zhang Q, Wang H, Ma Y, Zhang J, He X, Ma J, et al. Overexpression of NEDD9 is a prognostic marker of human gastric cancer. Med Oncol. 2014 Jul;31(7):33. doi: 10.1007/s12032014-0033-5.

23. Shi R, Wang L, Wang T, Xu J, Wang F, Xu M. NEDD9 overexpression correlates with the progression and prognosis in gastric carcinoma. Med Oncol. 2014 Mar;31(3):852. doi: 10.1007/s12032-014-0852-4.

24. Li P, Zhou H, Zhu X, Ma G, Liu C, Lin B, et al. High expression of NEDD9 predicts adverse outcomes of colorectal cancer patients. Int J Clin Exp Pathol. 2014 Apr 15;7(5):2565-70. PMID: 24966970.

25. Radulović P, Krušlin B. Immunohistochemical expression of NEDD9, E-cadherin and $\gamma$-catenin and their prognostic significance in pancreatic ductal adenocarcinoma (PDAC). Bosn J Basic Med Sci. 2018 Aug 1;18(3):246-51. doi: 10.17305/ bjbms.2018.2378.

26. Li Y, Fu L, Wong AM, Fan YH, Li MX, Bei JX, et al. Identification of genes with allelic imbalance on $6 \mathrm{p}$ associated with nasopharyngeal carcinoma in southern Chinese. PLoS One. 2011 Jan 20;6(1):e14562. doi: 10.1371/journal.pone.0014562. 


\section{Sažetak \\ POZITIVNA EKSPRESIJA NEDD9 U KARCINOMIMA GLAVE I VRATA POVEZANA JE S BOLJIM PREŽIVLJENJEM}

\section{Ledinsky Opačić, K. Gršić, S. Šitić, I. Penavić, M. Pastorčic Grgić i B. Šarčević}

Cilj je bio utvrditi imunohistokemijsku ekspresiju proteina NEDD9 i moguću povezanost ekspresije s veličinom tumora $(\mathrm{T})$, statusom regionalnih limfnih čvorova $(\mathrm{N})$, kliničkim statusom bolesti (TNM) i preživljenjem bolesnika s planocelularnim karcinomom glave i vrata. Analiziran je 131 bolesnik s primarnim tumorom lokaliziranim u orofarinksu, hipofarinksu i larinksu, a bolesnici su praćeni najmanje pet godina nakon inicijalnog kirurškog liječenja. Studija je uključivala 128 muškaraca i tri žene, medijan životne dobi od 62,0 (raspon 53,0-68,0) godine. Ukupno je 105 (95\%) bolesnika imalo pozitivan NEDD9 vidljiv imunohistokemijskim bojanjem citoplazme. Nije nađeno značajne razlike u ekspresiji NEDD9 u odnosu na status TNM. Bolesnici s pozitivnom ekspresijom NEDD9 imali su značajno viši medijan (IQR) razdoblja preživljenja: 51,0 $(15,0-60,0)$ mjesec prema 22,5 (9,0-55,0) mjeseca kod bolesnika s negativnom ekspresijom NEDD9 ( $\mathrm{p}=0,048)$. Negativna ekspresija NEDD9 pod kontrolom utjecaja drugih varijabla imala je značajan omjer rizika, uključujući Coxov proporcionalni model rizika (HR) od 2,10 (95\% CI: 1,23-3,58; p=0,006). Rezultati naše studije su pokazali da ekspresija NEDD9 može biti nezavisan prognostički biljeg u bolesnika s karcinomom glave i vrata s obzirom na podatke o ukupnom preživljenju i smrtnosti.

Ključne riječi: Glava i vrat, tumori; Planocelularni karcinom glave i vrata; Imunohistokemija; Tumori, određivanje stadija; Preživljenje bez znakova bolesti; Smrtnost 